\title{
Cartas em foco: \\ Clarice Lispector e o teatro
}

André Luís Gomes*

Resumo: Opresente artigo procura analisar as correspondências de Clarice Lispector, destacando o envolvimento da escritora com o teatro através de suas apreciações sobre a arte dramática e o interesse pelo panorama teatral da época. Apresentamos, ainda, um artigo jornalístico - inédito em livro-em que Clarice Lispector comenta a encenação da peça J.B., do poeta Archibald Mac Leish, sucesso de crítica e de público na Broadway, em 1958.

Palavras-chave: Literatura Brasileira; Epistolografia; Teatro; Clarice Lispector.

Quando tinha nove anos, eu vi um espetáculo e, inspirada, em duas folhas de caderno, fiz uma peça em três atos, não sei como. Escondi atrás da estante porque tinha vergonha de escrever.

Clarice Lispector ${ }^{1}$

título desse artigo, Cartas em foco: Clarice Lispector e o teatro, estabelece uma relação que, a princípio, pode parecer estranha, pois

* Doutor em Literatura Brasileira pela USP.

1. LISPECTOR. 20 out. 1976. 
imediatamente surge a pergunta: Clarice escreveu peças teatrais? Essa escritora é conhecida e reconhecida como romancista e contista, mas não como dramaturga. Então, por que estabelecer essa relação? De fato, além da experiência infantil mencionada na epígrafe, que recebeu o título Pobre menina rica, ela deixou somente um pequeno texto dramático, a tragédia A pecadora queimada e os anjos harmoniosos, considerada por alguns estudiosos apenas um esboço de uma peça teatral.

A escritora demonstra não só interesse pelo teatro como espectadora - o que fica registrado em suas cartas a amigos que se dedicam ao teatro ou não - mas também conhecimento da arte dramática enquanto cronista de teatro, entrevistadora de atores, atrizes, dramaturgos e tradutora de peças teatrais.

Mas, afinal, o que pensava Clarice Lispector sobre o teatro? Que conhecimento teria a respeito da arte dramática? Teria experimentado a linguagem típica do gênero dramático em seus textos, uma vez que afirmou "gêneros não me interessam mais. Interessa-me o mistério"? ${ }^{2}$ E como via as adaptações de seus textos? Buscamos, neste trabalho, responder a essas perguntas a partir das correspondências da escritora.

A correspondência enviada e recebida por Clarice Lispector $^{3}$ é extremamente esclarecedora para aqueles que se dispõem a decifrar seus textos literários e foi fundamental para a organização e elaboração das várias biografias da escritora existentes. Transcrita e publicada no livro Correspondências/Clarice Lispector, facilita a pesquisa e amplia o prazer daqueles que buscam conhecer um pouco mais sobre essa mulher que escreveu sobre as inquietações de sua época, suas descobertas e, assim, descortinou um mundo desconhecido. Como em um teatro em que os elementos vão sendo revelados, primeiramente ao abrirem-se as cortinas, depois ao acenderem-se os spots, e sucessivamente a cada aparição de uma nova personagem, Clarice vai revelando sua própria história contando e se contando - em seus textos literários e na correspondência.

A correspondência é um desses focos que revelam minúcias, trazem informações e conhecimentos sobre a autora e sobre seus amigos correspondentes.

2. LISPECTOR. Máquina escrevendo, em $A$ descoberta do mundo, p. 347.

3. À Fundação Casa de Rui Barbosa foram doados muitos dos pertences da escritora - documentos pessoais, produção intelectual própria e de terceiros, recortes de jornais e correspondências, que compõem o Inventário do Arquivo Clarice Lispector. VASCONCELLOS (Org.), 1993.

4. LISPECTOR, 2002. 
As cartas são reveladoras do universo pessoal e ficcional da escritora, tornando-se quase impossível adentrar o universo clariciano e tentar compreendê-lo sem a leitura desse material. Expõe detalhes de uma Clarice que se esforça por ser uma mulher comum, esposa e mãe de dois filhos, que escreve cartas, sentindo a ausência de seus parentes e amigos e também de si própria. A remetente, às vezes, tenta, mas não consegue nem mesmo se decifrar e sucumbe diante da impossibilidade, como escreve a seu amigo Lúcio Cardoso:

(...) Sabe, Lúcio, toda a efervescência que eu causei só veio me dar uma vontade enorme de provar a mim mesma e aos outros que eu sou mais do que uma mulher. Eu sei que você não crê. Mas eu também não o acreditava, julgando o q. tenho feito até hoje. É que eu não sou senão um estado potencial, sentindo que há em mim água fresca, mas sem descobrir onde é a sua fonte.

Dessa forma é que luzes em resistência deixam determinados fatos em penumbra para a própria autora e outros são evidenciados por uma luz a pino. E, assim, como em um apagar e acender de spots, os textos literários e as cartas ora devem ser colocados em um mesmo foco para o esclarecimento de minúcias que, em se tratando de Clarice, às vezes são revelações grandiosas, ora devem ser iluminados separadamente para que se capte o detalhe em luz estourada, como dizem os iluminadores teatrais.

Como iluminadores iremos focar, nas correspondências, apreciações e comentários de Clarice sobre o teatro, desvendando, ao mesmo tempo, a mulher que vai ao teatro para apreciá-lo e em busca de entretenimento, ou realizando uma atividade profissional. Quando necessário, vamos recorrer aos textos literários para confirmar comentários, informações e analisar a influência em sua obra do que Clarice assistia no teatro.

Em cartas enviadas pela escritora entre as décadas de 1940 e 1970, reunidas no livro mencionado, pode-se notar que o hábito de freqüentar teatros na infância não fora abandonado pela Clarice adulta, que se casa, em 1943, com Maury Gurgel Valente, seu colega na Faculdade de Direito do Largo São Francisco. O casal é obrigado a viajar e reside em diversos lugares, como Belém do Pará, indo depois para a Europa e Estados Unidos. Nesse período, a correspondência

5. Carta ao escritor Lúcio Cardoso, Belo Horizonte, 13.7.1941. LISPECTOR, 2002, p. 15. 
com os amigos é freqüente e, nas cartas, nomes de peças teatrais assistidas aparecem, algumas acompanhadas de comentários sobre a atuação de atores/atrizes, sobre os diretores e, às vezes, sobre o texto teatral.

Lúcio Cardoso foi um dos grandes amigos da escritora e muitas cartas foram escritas por ela para o escritor, poeta e dramaturgo que tanto a fascinou. A carta que abre o livro Correspondências/Clarice Lispector, à qual pertence a citação anterior, está cercada de insinuações, silêncios e mistérios, estampando uma proximidade maior entre ambos, a tal ponto que a remetente o adverte no final: "Esta você não precisa 'rasgar'...". Tal proximidade mereceu subitem especial na biografia escrita por Nádia Battella Gotlib, cujo título, "Uma grande amizade?", insinua que é possível que tenha havido entre os dois mais do que uma simples amizade, uma paixão. A biógrafa cita um depoimento de Francisco de Assis Barbosa sobre essa possibilidade:

Clarice conheceu Lúcio Cardoso na Agência Nacional. Escritor em plena ascensão exerceu sobre ela verdadeira fascinação. Claro que esse encontro foi muito importante. Marcou muito a vida dos dois. Em mais de uma oportunidade, no livro póstumo ( $A$ descoberta da vida ou do mundo) Clarice se reporta com entusiasmo a essa amizade. Acompanhei o dia-a-dia de Clarice. Ela me falava do seu deslumbramento por Lúcio, ao mesmo tempo que me punha ao corrente do namoro com o colega da faculdade. Conversávamos sobre nossas reportagens e lemos juntos os livros de poemas que iam aparecendo: Fernando Pessoa e Cecília Meireles, Bandeira e Drummond.

Na biografia escrita por Lícia Manzo, a amizade com Lúcio Cardoso também é destacada:

(...) No mundo do jornalismo descobre grandes amigos e afinidades, entre elas o escritor Lúcio Cardoso. Imediatamente eles se tornam grandes amigos. A admiração recíproca, a intensa cumplicidade, o intercâmbio de seus universos criativos, tudo isso tornava Lúcio e Clarice mais que irmãos. É a ele que Clarice mostra, pela primeira vez, as incontáveis notas soltas que viriam a compor Perto do coração selvagem.

6. GOTLIB, 1995, p. 161.

7. MANZO, 1997 , p. 12. 
É esse intercâmbio criativo que nos interessa particularmente, uma vez que Lúcio Cardoso, além de romancista, dedicou-se ao teatro não só como dramaturgo, mas também como encenador e incentivador da arte dramática.

Clarice escreve várias cartas ao amigo dos mais variados lugares onde ela se encontra: de Vila Rica, escreve uma carta-bilhete no dia 10 de janeiro de 1942; quando está em Belém, envia correspondência mais longa e deixa claro que telefonemas são também um meio de manter o contato com o amigo que se recusa a permitir uma proximidade maior entre ambos, como se pode entrever logo no primeiro parágrafo da carta: "Quando eu telefonei para você pra me despedir fiquei aborrecida com um engano seu. Eu disse que nunca tinha podido chegar + perto de seus problemas porque você nunca deixava (...)”. . Enquanto Clarice está sempre escrevendo para o amigo, Lúcio parece nem mesmo responder às cartas, como podemos deduzir a partir de outra carta também escrita em Belém, graças ao contentamento da escritora com o artigo de Lúcio Cardoso publicado no Diário Carioca, sobre o romance Perto do coração selvagem:

Imagine que eu estava junto da mesa, pronta para escrever pra você e contar coisas, quando bateram à porta e trouxeram-me, vindo do Rio, o que você publicou no Diário Carioca. Isso valeu como se você tivesse respondido à minha primeira carta... Gostei tanto. (...)

O intercâmbio entre eles aumenta na mesma intensidade que a produção literária e intelectual de ambos. Clarice encontra em Lúcio um leitor e crítico de seus romances, um amigo com quem ela pode contar e a quem pode até fazer pedidos inusitados, como em carta de 24 de maio de 1944, na qual pede que ele retire uma vírgula que a "incomoda horrivelmente" em um "pedaço do romance para Condé, 'Atlântico'”. ${ }^{11}$ De Natal, Clarice volta a escrever

8. Lúcio Cardoso escreveu as peças O escravo, 1937 (representada em 1943); O coração delator, s.d.; A corda de prata, 1947; O filho pródigo, 1947; Angélica, 1950

9. LISPECTOR, 2002, p. 36.

10. Na carta não há data. Podemos deduzir que foi escrita na data da publicação do artigo, 12.3.1944, ou em data próxima. Clarice escreve do Central Hotel, em Belém, PA.

11. Teresa Montero esclarece em nota de rodapé: "O pedaço do romance é 'Bonecos de burro' e está em O lustre. Rio de Janeiro: Agir, 1946". Cf. também GUIMARÃES, 1998. 
para Lúcio indicando Paulo Mendes para algumas conferências no Rio e, de Nápoles, em 30 de setembro de 1944, Clarice envia um bilhete:

Mandei uma carta pra você; não sei se já recebeu.

Transmito-lhe agora esse Efebo da Itália. Até parece um pouco com você... Não me esqueça. ${ }^{12}$

Em Nápoles, a solidão e o frio intensificam a saudade do amigo, e Clarice chega a implorar: "Não me esqueça, Lúcio, não me considere exilada. A distância nada quer dizer acredite. Escreva-me, diga coisas, diga-me sobretudo do que você quiser - eu ia dizendo, ou então nada escreva para lhe dar liberdade; mas não, eu exijo uma palavra fria e curta que seja”. ${ }^{13}$ Em outra carta, de 15 de novembro, incompleta, Clarice conta que está lendo, em italiano, romances policiais, e cita Anfitrião $38 .^{14}$

Depois de tantas cartas da amiga, Lúcio escreve justificando-se: "se nem sempre tenho escrito carta, acho que tenho por outros meios procurado provar em tudo, não?" Comenta o romance O lustre e sua nova novela, O anfiteatro.

Em 26 de julho de 1947, Lúcio escreve para Clarice uma carta dedicada quase que exclusivamente a seu envolvimento com o teatro, informando que fundou uma companhia, o Teatro de Câmera, que apresentará, no Teatro Glória, o seguinte repertório de peças: A corda de prata, do próprio remetente; O jardim, de Cecília Meireles; Mensagem sem rumo, de Agostinho Olavo; Para além da vida, de Rebelo de Almeida, e o clássico O anfitrião, de Antonio José. Empolgado, cita o nome dos grandes cenaristas, Santa Rosa, Burle Marx e o nome das duas estrelas principais, Alma Flora e Maria Sampaio e, finalmente, faz um pedido à amiga:

Agora, como é um empreendimento profissional, e necessitamos de grande publicidade, gostaria que você, caso pudesse ou se interessasse, escrevesse quatro ou cinco linhas dizendo o que pensa e apoiando a iniciativa do Teatro de Câmera. Explico melhor o título: é um teatro destinado a enfrentar essa idéia de que o teatro é o espetáculo, a grande montagem. Está para

12. LISPECTOR, 2002, p. 53.

13. LISPECTOR, 2002, p. 57.

14. LISPECTOR, 2002, p. 58

15. LISPECTOR, 2002, p. 60 
Disponível em: http://www.letras.ufmg.br/poslit

este último, como o trio ou o quarteto para a sinfonia e o concerto. O que não significa que o trio seja menos música, ou menos profundo. Ao contrário. Resta esclarecer que não há nenhum ranço político, e que acolhemos todo mundo, desde Cecília Meireles a Jorge Amado, que vai nos dar uma peça chamada $A$ estrangeira. Há também uma de Nelson Rodrigues, Electra. Com esses dados, você poderá nos enviar um apoio livre de qualquer suspeita de "reacionarismo"... ${ }^{16}$

Nota-se, na carta-resposta enviada ao amigo, que Clarice detém certo conhecimento acerca da arte dramática, citando características específicas do que ela entende como boa realização cênica:

Os autores, cenaristas e artistas que trabalham para o Teatro de Câmera asseguram a realização de seu propósito - fazer o gesto recuperar o seu sentido, a palavra, o seu tom insubstituível, permitir que o silêncio, como na boa música, seja também ouvido, e que o cenário não se limite ao apenas decorativo e nem mesmo à moldura apenas - mas que todos os elementos, aproximados de sua pureza teatral específica, formem a estrutura indizível de um drama. ${ }^{17}$

A escritora pode não ter sido uma leitora daquele que é considerado renovador na história do teatro na Rússia, Constantin Stanislavski, mas ao advertir sobre a importância do "gesto", o faz como o famoso fundador do Teatro de Arte de Moscou que, ao descrever uma aula em que "o Diretor passou (...) das poses para os gestos", salienta a importância do gesto no palco por meio de exercícios para que os atores dominem uma "técnica de controle muscular". ${ }^{18}$

Quanto ao uso da palavra, assim como Clarice ressalta que o ator tem a função de recuperar o tom "insubstituível da palavra", em A construção da personagem, Stanislavski afirma:

Nunca se deve usar no palco uma palavra sem alma ou sentimento. Lá as palavras não se podem apartar das idéias tanto quanto não se podem apartar da ação. Em cena, a função da palavra é a de despertar toda a sorte de sentimentos, desejos, pensamento, imagens interiores, sensações

16. LISPECTOR, 2002, p. 144-145.

17. LISPECTOR, 2002, p. 146-147.

18. STANISLAVSKI, 1986a, p. 132. 
visuais, auditivas e outras, no ator, em seus comparsas e - por intermédio deles, conjuntamente - no público. ${ }^{19}$

Além da palavra, a autora destaca o silêncio e o compara a uma boa música. Ao silêncio, Lispector atribui valor sugestivo e instigante, do qual diretores devem tirar partido para que o mesmo seja ouvido. Assim, para ela, o silêncio faz parte do conjunto de sonoridades presentes em uma encenação teatral e deve ser utilizado com função específica, integrando-se aos outros elementos auditivos com característica específica.

Da mesma forma, os hiatos na escritura clariciana dizem, às vezes, mais do que as palavras, pois sugerem, incomodam. Como afirma Olga de Sá, "está sempre à espreita da romancista a tentação do silêncio, como única expressão digna e adequada dessa outra face do ser; porque o silêncio não trai, porque o silêncio não diz de menos, porque o silêncio é, em certo sentido absoluto". ${ }^{20} \mathrm{~A}$ essa tentação ao silêncio, Clarice se rende de forma exacerbada na tragédia $A$ pecadora queimada e os anjos harmoniosos, único texto teatral publicado pela autora em que, como analisaremos, a protagonista não tem voz durante todo o texto. Clarice também vai traduzir, na década de 1960, A gaivota, de Tchecov, que

tira um tão sutil partido do jogo dos silêncios e dos ruídos, da interferência das vozes tagarelando e dos sons da natureza, que Stanislavski deve ter tomado consciência do poder sugestivo daquilo que ele chama de paisagem auditiva. (...) Numa carta a Tchecov, datada de 10 de setembro de 1898, Stanislavski explica que está utilizando em $A$ gaivota o coaxar dos sapos "exclusivamente para dar a impressão de um silêncio completo. No teatro, o silêncio expressa-se através de sons e não pela sua ausência. Caso contrário, seria impossível dar uma ilusão de silêncio (...)" ${ }^{21}$

Completando suas apreciações sobre os elementos que devem compor uma encenação, Lispector não deixa de mencionar o cenário, que não deve se limitar ao decorativo. Da mesma forma que o gesto deve recuperar seu sentido, a palavra e o silêncio devem ser ouvidos, o cenário deve se somar a esse conjunto de forma harmoniosa e com uma funcionalidade específica,

19. STANISLAVSKI, A construção da personagem, 1986b, p. 138.

20. SÁ, 1979, p. 136.

21. ROUBINE, 1998, p. 155. 
deixando de ser apenas um elemento figurativo para interferir, junto aos outros elementos, na multiplicação das possibilidades de sentido da imagem cênica e formar "a estrutura indizível de um drama", citando as palavras finais de Lispector, apoiando o Teatro de Câmera.

Na carta escrita de Paris, em janeiro de 1947, para as irmãs Elisa e Tânia Kaufmann, ${ }^{23}$ Clarice descreve a atribulada vida parisiense, reclama de não ter tempo e, por isso, sentir-se "outra pessoa". Com certa angústia, desabafa: "Quem está se divertindo é uma mulher que eu não conheço, uma mulher que eu detesto, uma mulher que não é a irmã de vocês".

Clarice sobrepõe, em períodos curtos, vários divertimentos. Entre os citados, estão os almoços e jantares nos quais conhece pessoas novas como Santiago Dantas, Augusto Frederico Schmidt e o ator de cinema Victor Fraceu (sic) e os "ótimos" teatros. Conta que foi ao musical de Madeleine Gray, que "cantou horrível”, e acrescenta: "Vimos Electra, de Eugene O'Neill, uma beleza".

As frases são sucintas e nada reveladoras sobre o que considera "uma beleza" no espetáculo, mas, pelo menos, se nota que o teatro é uma "diversão" rotineira e que o interesse pelas encenações também é grande.

Isso pode ser inferido também pelas cartas recebidas por Clarice, durante sua estada em Berna, nas quais os amigos sempre informam sobre os acontecimentos culturais no Brasil e, entre eles, as novidades do mundo teatral. Nas cartas de Bluma Wainer, por exemplo, há referências a peças teatrais, como no trecho da carta enviada no dia 11 de agosto de 1947:

Noutro dia fui ver a première de Terras dos sem fim ( sic) - adaptação para o teatro de Graça Mello. Não gostei. Muito longo, quadros rápidos como se fossem snaps de cinema, não tem a atmosfera do livro e o Ziembinski fazendo o coronel do sertão é de matar, com sua pronúncia e jeitos de

22. LISPECTOR, 2002, p. 147.

23. LISPECTOR, 2002, p.115-116.

24. Segundo as "Notas biográficas" contidas no livro Correspondências/ Clarice Lispector, Bluma Chafir Wainer era "jornalista e fotógrafa. Viveu em Paris com o marido, Samuel Wainer, por alguns anos, na década de 40, quando então conheceu Clarice. Retornou para o Rio em 1948. Clarice acompanhou os últimos dias de Bluma, que morreu precocemente em 1951." (LISPECTOR, 2002, p. 319). 
Disponivel em: http://www.letras.ufmg.br/poslit

Europa central. Foi muita gente, e muita gente que não se reunia no mesmo lugar há muito tempo. (...)

Não há uma resposta de Clarice para essa carta. Encontramos uma série de outras de Bluma Wainer que, em 3 de março de 1948, entre notícias sobre publicações de Carlos Drummond e sobre Ceschiatti, acrescenta informações sobre o Teatro do Estudante no Rio de Janeiro:

Pascoal Carlos Magno tem feito um grande trabalho com o Teatro do Estudante que conseguiu realizar Hamlet e mantê-lo em cartaz durante 6 semanas. E anuncia que voltará na próxima semana, a pedido. Agora estréia A Castropeça do português, que não conheço e nem fui ver ainda. Dulcina anuncia para breve L'aigle a deux tête - que tal o Odilon fazendo o papel de Jean Marrais? (nome dele não é assim que escreve, mas não faz mal). Teatro há mesmo o do Estudante, Procópio e Dulcina que ainda não está funcionando, o resto, são filmes horríveis e só. Não há nada para se ver nem ouvir. (... $)^{26}$

Em outra carta, enviada, do Rio de Janeiro em 14 de agosto de 1951, para Eliane Gurgel Valente, ${ }^{27}$ percebemos que Clarice encontra o que "ver e ouvir", pois, junto a amigos, conta que foi assistir a uma "estranha peça de Nelson Rodrigues" e Morte de um caixeiro viajante, de Arthur Miller.

25. LISPECTOR, 2002, p. 149.

26. LiSPECTOR, 2002, p. 169. Décio de Almeida Prado comenta a importância "de um pequeno número de pioneiros" que enfrentaram o "descrédito em que havia caído o teatro" na década de 1940. Entre os pioneiros, estão Alfredo Mesquita, em São Paulo e Paschoal Carlos Magno, no Rio de Janeiro, sobre o qual o crítico sintetiza: “(...) O segundo (Paschoal Carlos Magno, 1906-1980), como diretor do Teatro do Estudante do Brasil ou como incansável animador de festivais realizados nos mais diversos lugares, nunca dispensou por completo aquela margem de improvisação inerente à atividade amadora, exercendo influência mais pelo entusiasmo do que pela preocupação com os aspectos artesanais da arte de representar. Pode-se dizer que Alfredo Mesquita restringiu deliberadamente o seu campo de ação, para explorá-lo em profundidade, empenhando-se em aparelhar moral e tecnicamente o nosso incipiente teatro profissional, ao passo que Paschoal Carlos Magno, agindo antes em extensão, inclusive geográfica, alargou o seu raio de atividades até abarcar praticamente o Brasil inteiro". PRADO, 1998, p. 39.

27. LISPECTOR, 2002, p. 194. 
Deve-se certamente à singularidade e à extravagância do teatro de Nelson Rodrigues o uso do adjetivo "estranha" para caracterizar a peça do dramaturgo, possivelmente, Valsa n. 6 , um monólogo estrelado por Dulcinha, irmã de Nelson. O monólogo estreou em uma época em que o dramaturgo e jornalista passava por problemas financeiros, como relata Ruy Castro:

A 6 de junho (...), Nelson Rodrigues estreava uma nova peça, quase em silêncio: Valsa n. 6. E bem de acordo com as condições que agora tinha de enfrentar: um único ator em cena e, não por acaso, sua irmã, cenário quase nu (apenas uma cortina vermelha e um piano branco); e que só era levada uma vez por semana, às segundas-feiras, no Teatro Serrador. (...) É certo que Nelson não estava em condições de montar nada maior que um monólogo, mas havia outra razão para ele acreditar em Valsa n. 6: o espantoso sucesso, em junho do ano anterior, de outro monólogo, As mãos de Eurídice, de seu amigo Pedro Bloch. ${ }^{29}$

Quando Clarice assiste ao monólogo, possivelmente em 1951, Vestido de noiva já havia revolucionado os palcos brasileiros, em 1943, graças não só à renovação temática e concepção cênica, mas principalmente a uma linguagem nova que alterava o panorama teatral brasileiro. Na obra de 1951, uma menina, Sônia, narra sua aventura amorosa com um médico que era casado.

28. Valsa $n$. 6 é a única peça encenada de Nelson Rodrigues em 1951. No capítulo "Encenações", Sábato Magaldi apresenta o seguinte comentário sobre a encenação do monólogo:

"A estréia de Valsa n. 6, escrita depois de Senhora dos Afogados, ocorreu antes, em 6 de agosto de 1951, no Teatro Serrador do Rio, para uma temporada às segundas-feiras. A razão era simples: Nelson fez o monólogo para sua irmã Dulce Rodrigues e a montagem não oferecia problemas. A primeira rubrica pede um cenário sem móveis, tendo ao fundo cortinas vermelhas. No palco, apenas um piano branco, diante do qual está sentada a adolescente, vestida 'como que para um primeiro baile'.

Mme. Morineau, que dirigiu o espetáculo, concedeu-me entrevista, publicada no Diário Carioca de 15 de julho de 1951. Nela, a atriz-encenadora admitiu que, talvez, 'a peça não seja compreendida de um momento para outro (à semelhança de Dorotéia, que não teve êxito de bilheteria, em razão de seu hermetismo). Mas, pelas qualidades (tem muita beleza), pode prender a platéia, influindo, nisso, o toque delicado, a idade da personagem, encantadora nos seus quinze anos. Há uma mistura de romantismo e espírito moderno, muita poesia, uma nota diferente tocada por Rodrigues". MAGALDI, 1987, p. 102.

29. CASTRO, 1992, p. 233. 
Entretanto, quando começa o monólogo, Sônia já fora esfaqueada por esse homem. A menina adentra a cena, toca a valsa e reconstitui suas memórias por intermédio da música e de palavras desconexas como uma figura fantasmagórica. Sobre a personagem, escreve Sábato Magaldi:

Que fatalização distinguirá a vida breve da adolescente Sônia, protagonista de Valsa n. 6? Como as jovens de sua idade e dos anos em que foi escrito o monólogo (1951), ela se alimenta de sonhos poéticos. O namorado, a família, o piano, os temores naturais povoam a mente que desperta para o mundo. Entretanto, à espreita está o velho médico, para assassiná-la de forma absurda. A morte colhe-a, antes que ela tenha tempo de construir a maturidade. $\mathrm{O}$ velho médico, expresso apenas por meio das palavras de Sônia, é um desses seres obscuros, que descansam no crime a inclinação louca por uma menina. ${ }^{30}$

Uma década depois de assistir ao monólogo rodriguiano, Clarice publica, em Laços de família, os contos "Preciosidade", "Começos de uma fortuna" e "Mistérios em São Cristóvão", em que jovens adolescentes vão adentrar o mundo dos adultos. Esse rito de passagem, em "Preciosidade", é impulsionado por experiência sexual abrupta e violenta, aproximando-se das peças rodriguianas. Podemos apontar nesses contos ecos do monólogo escrito por Nelson Rodrigues, entrevistado por Clarice, que escreverá uma crônica intitulada "Um caso para Nelson Rodrigues", assumindo no título o diálogo com o autor de Valsa n. 6.

Quanto ao espetáculo Morte de um caixeiro viajante, o ator Jaime Costa, elogiado pela espectadora Clarice - que insere sua opinião pessoal sobre a atuação do elenco: "Ele ótimo, os outros menos","1 -, certamente interpretou o fracassado caixeiro viajante com a mesma grandeza e a habilidade teatral com que Arthur Miller concebeu a personagem e o texto como um todo.

Em capítulo sobre o dramaturgo, ${ }^{32}$ Sábato Magaldi enaltece a modernidade de Arthur Miller e reconhece que em sua dramaturgia "há apenas atualização dos processos tradicionais, aplicados com inteligência aos estímulos do momento". Os estímulos do momento, explica o crítico, são "as forças sociais, propondo uma fórmula política para vencer as injustiças”. Se Bertolt Brecht criou um novo processo dramático, incluindo esses novos estímulos, Arthur Miller

30. MAGALDI, 1987 , p. 25.

31. MAGALDI, 1987, p. 194.

32. MAGALDI, 1989 , p. 360. 
apenas atualizou a dramaturgia, e em Morte de um caixeiro viajante temos um conflito social que desencadeia a desestruturação familiar e individual. As injustiças sociais, o desemprego, a inadaptação de um jovem ao mercado de trabalho, a exploração da mão-de-obra jovem e a exclusão do velho em um sistema hostil à velhice são os estímulos que sedimentam a peça. Este injusto modelo social provoca o fracasso do poder patriarcal em um núcleo familiar em que o pai, tomado pela vaidade e pelo orgulho, é devorado pelas ilusões capitalistas e não quer admitir o próprio fracasso. Se na juventude o caixeiro viajante gozava de reconhecimento profissional e julgava que a dedicação ao trabalho fosse lhe render um futuro melhor, a velhice lhe trouxe não só o desgaste físico, mas a certeza de que fora usado e, não sendo mais produtivo, é agora mão-de-obra dispensável. Os conflitos familiares crescem na medida em que os filhos também não correspondem aos desejos e anseios deste pai que esperava realizar nos filhos os sonhos que sempre alimentou. Entre os filhos e o pai, a mãe tenta inutilmente reconstruir as crenças familiares e individuais, mas a tentativa é um malogro: a suspeita de que o caixeiro pensava em suicídio se concretiza. Com o suicídio, resta à mulher se lamentar que, tendo quitado o financiamento do imóvel, o marido não mais estará a seu lado para desfrutar da tranqüilidade obtida graças ao esforço do caixeiro viajante. Como afirma Sábato Magaldi:

A peça mostra bem a falta de perspectiva da burguesia média na sociedade contemporânea. A polarização das classes sociais condena-a a proletarizarse e, em última análise, é esse movimento dialético que transparece da ação de A morte de um caixeiro viajante. A iniciativa do vendedor ambulante cede lugar à racionalização do trabalho. Quem, diante do texto, não sente uma palavra de advertência e um enorme susto?

Em se tratando de Clarice Lispector, deve-se crer que a autora se manteria calada diante da questão, pois certamente sentiu as advertências que o texto reverbera e se assustou diante da proletarização da família, do descaso advindo com a velhice e do conseqüente desespero que leva o pai ao suicídio. Se Bertolt Brecht e Arthur Miller, guardadas as devidas diferenças, apreenderam as coordenadas sociais do momento e utilizaram o teatro como forma de questionar as novas relações sociais e trabalhistas para mostrar a falta de perspectiva da burguesia média e a exploração capitalista, Clarice vai denunciar, também a seu modo, o quanto a sociedade capitalista é excludente, a conseqüente falta de perspectiva da burguesia e, principalmente, do proletariado. Entretanto, 
Clarice tem um modo peculiar de tematizar as injustiças sociais e as conseqüências de um mundo capitalista na sociedade e no indivíduo: sua linguagem é metafórica e reflexiva; nos hiatos do texto é que se pode reconhecer o grito social; nos perfis femininos é que se desenha a submissão e a infelicidade de mulheres presas a um mundo burguês e hipócrita. Deve-se a esse modo peculiar de exprimir o instante social que vivencia as críticas de que foi vítima, tendo sido acusada de não tematizar em seus textos as más condições sociais do país e de ser uma escritora burguesa. Os críticos ortodoxos ${ }^{33}$ exigiam uma literatura engajada e semelhante à produzida pela geração regionalista, enquanto a escritora mergulhava suas tramas no dilema pessoal e intimista das personagens, frente às discrepâncias sociais vigentes no meio urbano. O patrulhamento ideológico a incomodava, o que é ironizado por Caio Fernando Abreu:

De Clarice em Clarice, cheguei em A hora da estrela, de 1997. Ela já vinha sofrendo da implicância da crítica: que estava se diluindo, que era contista, não romancista, que Uma aprendizagem ou O livro dos prazeres era perfeitamente vazio. A hora da estrela saiu num momento político complicado (qual não é?), na transição da mais dura repressão para uns tímidos começos de liberdade. Grandes policiamentos da intelectuália: boa era a latinidad, discutia-se o que seria "a realidade brasileira", e a "boa" literatura devia ter, obrigatoriamente, algum bóia-fria. E lá vinha Clarice com suas subjetividades transcendentais...

Mas o último romance escrito pela autora, A hora da estrela, é a resposta maior e derradeira da escritora que insistia ser uma nordestina e que, por um incidente de dois meses, nascera na Ucrânia, mas fora criada e educada no Recife, com toda a falta de perspectiva que rondava a família judia. ${ }^{35}$ Caio Fernado Abreu então continua: "Pois ela vinha. E $A$ hora da estrela dava um banho de realidade brasileira, com aquela Macabéa nordestina tão tosca que não sabia nem passear: olhava parafusos nas vitrines. Nem conversar: repetia informações da Rádio Relógio. (...)".

33. Referimo-nos aqui ao porta-voz desses ortodoxos, Nelson Werneck Sodré, que chegou a dizer que Clarice escrevia só sobre a imaginação, não tinha compromisso com o povo e era uma escritora burguesa.

34. ABREU, mar. 1986.

35. Cf. WALDMAN, 1998, p. 93-104.

36. ABREU, mar. 1986. 
Se na história de uma "inocência pisada", de uma personagem que "tem direito ao grito" mas "não sabe gritar" chamada Macabéa, ficam escancarados assuntos como pobreza, fome e doença, em outros contos Clarice reproduz, com traços biográficos evidentes, a infância passada com dificuldades financeiras e de forma solitária, como em "Restos de carnaval", "Felicidade clandestina" e "Cem anos de perdão".

Esses contos de nítidas referências autobiográficas são publicados em 1971, portanto vinte anos após a data da carta em que Clarice se refere à encenação de Morte de um caixeiro viajante. Entretanto, podemos buscar, nos dois primeiros anos da década de 1950, o conto "Começos de uma fortuna", publicado em 1952, que se estrutura em torno de uma família pequeno-burguesa na qual o pai mistura "autoridade e compreensão", a mãe mistura "compreensão e princípios básicos" e o filho adolescente, Artur, se sente incompreendido.

Clarice Lispector, assim como Arthur Miller, "teve a ciência de retratar aspectos fundamentais da aventura humana, dentro de uma clara visão do presente", como afirma Sábado Magaldi sobre o dramaturgo, o que aqui aplicamos também à escritora.

Em 1957, morando em Washington, Clarice envia uma série de cartas para o casal Veríssimo, ${ }^{38}$ com quem iniciou uma estreita amizade durante o período em que o casal morou em Washington, de 1953 a 1956.

37. Cf. MARTINS, 2002. Na primeira escala, "A cidade mãe (de útero a túmulo)", em subitem intitulado "Infância e fome - O espaço rememorado", o autor analisa com propriedade e aguçado espírito crítico os contos "Restos de carnaval", "Felicidade clandestina" e "Cem anos de perdão", mostrando que "contos e crônicas mais eminentemente autobiográficos, mas também outros textos nos quais a infância aparece tematizada, servem para complementar - como depoimentos ficcionalizados - uma visão sobre modos peculiares de subjetivação e algumas das relações de sociabilidade vivenciadas na cidade brasileira, nas primeiras décadas do século XX".

38. Érico e Mafalda Veríssimo são padrinhos dos filhos de Clarice, Pedro e Paulo, nascidos, respectivamente em 1948 e 1953. No ano do nascimento de Paulo, em Washington, Clarice trava amizade com o casal Veríssimo e com Alzira Vargas. Sobre a amizade com o casal Veríssimo, assim escreve Teresa Cristina Montero Ferreira:

"Outro casal que chegava a Washington (1953) era o escritor Érico Veríssimo e Mafalda, acompanhados dos filhos Clarissa e Luís Fernando. Érico fora convidado para substituir Alceu Amoroso Lima na direção do Departamento de Assuntos Culturais da União Pan-Americana, ligado à ONU. Assim que chegaram, receberam a visita de Maury e Clarice, no hotel. Começava nesse momento uma grande amizade entre os Veríssimo e os Valente". FERREIRA, 1999, p. 181.

No livro Correspondências/Clarice Lispector, há cópias dos bilhetes escritos pelos filhos de Clarice para os padrinhos. 
Em 30 de março de 1957, depois de comentar um bilhete que o filho Paulo escreveu, em inglês, para Mafalda Veríssimo e a carta de Pedrinho, escrita para Érico Veríssimo, informa que assistiu "à peça em que Clarissa e Dave trabalham" e insere o seguinte comentário sobre a atuação da filha do casal Veríssimo:

Clarissa ótima, natural. Com talento. Ela também acha que está perdendo tempo com os (...). Tudo que ela podia aprender com eles, já aprendeu, e mais, ultrapassou-os. Com o estímulo constante de Dave, ela está pretendendo ingressar no Arena. Mas tem um pouco de timidez e fica adiando. ${ }^{39}$

$\mathrm{Na}$ intenção de manter os compadres Érico e Mafalda informados sobre a filha Clarissa ou deixar que eles tenham, como afirma a própria Clarice em carta, uma saudade tranqüila, uma série de cartas é enviada e, na do dia 17 de novembro, Clarice conta que a irmã Tânia esteve uns dias com ela, que a mesma visitou o casal Gaffe e há, novamente, um comentário sobre a carreira da atriz Clarissa: “(...) eles estão bem um com o outro. O Dave não só apóia o Teatro de Clarissa, como quer que ela continue depois que o baby nascer (...)". ${ }^{40}$

As cartas recebidas por Clarice, durante sua permanência na Europa, comprovam o carinho que recebia de seu círculo de amizade:

Quanto à presença dos amigos, ela se faz pela via da correspondência. Alguns deles estavam na Europa, como é o caso do diplomata Ribeiro Couto. (...)

Outros the escrevem dos Estados Unidos. Lauro Escorel, por exemplo, conta-lhe, de Boston, em 20 de julho de 1946, como é sua vida na América do Norte, dá notícias de Vinícius de Moraes, que por lá passou indo em serviço diplomático para Los Angeles; fala-lhe de Guimarães Rosa, das leituras que está fazendo, e manda-lhe o artigo de Gilda de Melo e Souza sobre O lustre. (...)

Mas a correspondência mais assídua é com amigos do Rio, que lá continuam e cuja lembrança a escritora carrega para a Itália - entre eles, Manuel Bandeira, Rubem Braga, Paulo Mendes Campos, Francisco de Assis Barbosa, Lúcio Cardoso e Fernando Sabino. ${ }^{41}$

39. LISPECTOR, 2002, p. 224.

40. LISPECTOR, 2002, p. 234

41. LISPECTOR, 2002, p. 194. 
Outro correspondente é Paulo Francis, diretor da revista Senhor, que escreve a Clarice em janeiro de 1959, informando sobre o interesse em publicar o conto "A menor mulher do mundo". ${ }^{42}$ Ele afirma:

Nahum Sirotsky, Carlos Scliar, Luiz Lobo e eu, em 1959, resolvemos "abrigar" Clarice na revista Senhor. (...) Ela publicou praticamente todos os seus contos em Senhor. Fizeram grande sucesso, dentro dos limites da circulação da revista, que nunca passou dos 25 mil, mas que atingia muito mais gente do que isso, cuja influência na imprensa brasileira dispensa comentários. ${ }^{43}$

Um pouco antes, em dezembro de 1958, Paulo Francis publica, no Diário Carioca, um artigo de Clarice sobre J.B., uma peça do poeta Archibald Mac Leish, sucesso de crítica e de público na Broadway. Clarice assistiu ao espetáculo em Washington, anteriormente à estréia na Broadway, e envia o comentário a Paulo Francis, que resolve publicá-lo com exclusividade. Apesar de sua extensão, vamos transcrevê-lo por sua importância para nossa reflexão:

Uma peça do poeta Archibald Mc Leish, "J.B.", baseada no Livro de Jó, está fazendo sucesso de crítica e de público, na Broadway. (...) Clarice Lispector, escritora de primeira qualidade, enviou-nos suas impressões sobre o texto de Mc Leish, quando assistiu ao espetáculo, em Washington, anteriormente à estréia na Broadway. É esse comentário que oferecemos aos leitores, hoje, com exclusividade. (...)

Deu-se em Washington a pré-estréia da peça de Archibald MacLeish, J.B., agora no Teatro ANTA de Nova York. As reações foram variadas. Houve os que se reemocionaram com Job, houve os que se comoveram com "J.B.", o homem de negócios e os que choraram os próprios males, pois teatro é lugar quente neste frio daqui. Alguns consideraram a peça um acontecimento literário, que uma vez no palco, se transformou numa simples reafirmação do Antigo Testamento - com menos dramaticidade que este, e as melhores frases tiradas do próprio Livro de Jó.

J.B., porém, não é a dramatização de um incidente da Bíblia, nem a modernização da tragédia de Job. Diz o autor que construiu uma peça moderna dentro da antiga majestade bíblica, assim como os beduínos costumavam há uns trinta anos instalar rudimentares postos de gasolina dentro das ruínas de Palmira. Tanto ele como os beduínos, justificados pela necessidade. Durante cinco anos o tema de J.B. viveu nele, sem

42. Cf. GOTLIB, 1995, p. 309.

43. Apud GOTLIB, 1995, p. 310. 
encontrar o espaço que o emoldurasse. Até que a estrutura do poema de Job impôs-se como a ideal. Embora dois dos personagens acreditem que a peça é o próprio Livro de Job (Raymond Massey, representando Deus e Christopher Plummer, no papel de Satanás), J.B. (Pat Hingle) e sua família não foram inspirados na Bíblia.

J.B. existe hoje. E para McLeish, nos antigos gritos de Job, pedindo explicação para a perda de tudo, estão nossas vozes fazendo a mesma pergunta. É nesse ponto que as duas histórias mais se tocam. Job queria compreender o sentido de seu destino, saber por que um homem bom perdera os filhos, o amor da esposa e tudo o que possuía. Mas havia a falta essencial da razão. Pediu a Deus que lhe indicasse sua culpa, a culpa que justificaria a desgraça. Consolavam-no, convencendo-o mesmo contra sua própria certeza íntima, de que era culpado. Também nós estamos perplexos com desastres que arrasaram cidades e povos com a destruição de inocentes sem encontrar um motivo aceitável. Só que não temos o último refúgio da culpa que explicaria. Pois os que nos consolam, tornam a culpa impossível.

McLeish diz que ouviu o argumento de que as duas histórias diferem porque a idéia de Deus mudou muito desde o tempo de Job. Que Deus não é, como antes, o criador do universo, e que a ciência afirma não existir um criador controlando acontecimentos. Ao escrever sobre a peça, MacLeish sem estar ligado a nenhum credo lembra que Einstein tantas vezes sentiu, durante as pesquisas, que seguia o caminho de uma inteligência superior à sua. E lembra que, na história da humanidade, nada levou o homem "tão perto da imanência de uma criação infinita como a revelação de que as menores partículas de matéria inerte contêm um poder quase incomensurável". O Deus de Job lhe parece mais perto da geração de hoje do que de qualquer outro século.

Como Job, J.B. não está preparado para a perda inexplicável. J.B. - homem de negócios em plena prosperidade chamado, ao jeito moderno, pelas iniciais - tem no começo da peça tudo o que um homem pode desejar. Não é pessoa que estranha ter tanto, aceita o que lhe dá como direito seu. Não por ser um devoto, nem, como diz MacLeish, por ser um Babbit: é um homem cheio de vitalidade e calor humano que acredita em si mesmo e na sua vida. Não é um hipócrita; assim como outros americanos de sucesso, não crê que mereça mais do que os outros, mas tem consciência de que possui mais do que outros, e aceita.

Também ele quererá saber por que perde tudo. E, como todos nós, pergunta. O autor vê nossa época assombrada e dirigida pela necessidade de entender. Tudo hoje - ciência, artes - está cheio de pergunta. Nesse ponto as duas histórias se assemelham: "Job não é respondido pela vOZ que vem do vento rodopiante. É silenciado pela voz - silenciado por uma 
Disponivel em: http://www.letras.ufmg.br/poslit

das trinta ou quarenta linhas de maior grandeza em toda a literatura silenciado pelo poder e majestade e magnificência da criação. É levado não a entender, mas a ver. Como nós". E o que acontece quando ele vê mesmo sem entender é que tudo lhe é dado de novo, e Job aceita recomeçar. Não foi justificado nem entendeu. Mas aceita porque é um homem.

A esperança de MacLeish é uma fé. "... desde o começo dos tempos os seres humanos retomaram a vida de novo e de novo, geração após geração nunca porém, com uma coragem tão desesperada como nesses últimos e estranhos dias. Nossos contemporâneos já se sentaram, como Job, numa terra reduzida a cinzas, olhando em agonia a pele escorchada pelas bombas, fazendo a eterna pergunta de Job. Sabemos que eles se sentaram nessa terra. E também a nós poderá suceder o mesmo. Mas sabemos algo mais. Que até esses homens podem aprender, nas palavras de Yeats, a viver tudo de novo.

Talvez por coincidência - os lamentos de Job estão se ouvindo - a Escola de Música Juilliard apresenta, pela primeira vez nos Estados Unidos, o oratório dramático Job de Luigi Dallapiccola, há oito anos estreado em Roma. A execução do trabalho em escala dodecafônica leva trinta minutos. Frederick Prausntz conduz Frederic, Cohen dirige a parte teatral, TsengYou-Ho desenhou cenário e trajes. ${ }^{44}$

O texto de Archibald Mac Leish ${ }^{45}$ atualiza a passagem bíblica do "Livro de Jó". Em um mundo capitalista, J.B. é um bem-sucedido empresário que vive em sua mansão cercado por sua mulher, Sara, seus cinco filhos, David, de 13 anos; Maria, de 12; Jonas, de 10; Rute, de 8; Rebeca, de 6, e duas robustas empregadas. O prólogo metalingüístico inicia-se com dois atores decadentes, srs. Zuss e Nickles, discutindo a possível representação de Job e acabam decidindo que sr. Zuss fará o papel de Deus e Nickles, o de Satã. Colocam as máscaras e iniciam a representação. Na primeira cena, temos J.B., Sara e seus filhos reunidos em torno de uma mesa, revelando todo o poder aquisitivo da família. O casal é religioso e temente a Deus. E quando Sara diz temer o fato de terem tanto, J.B. nega ter tido sorte e afirma: "sempre soube que Deus estava comigo. E tentei demonstrar que sabia - não em palavras apenas". Na segunda cena, sr. Zuss defende J.B., pois acredita que ele jamais deixará de louvar a Deus. Nickles refuta a crença e, de forma irônica, diz a Zuss: "Mas estende a

44. LISPECTOR, 21 dez. 1958.

45. MAC LEISH, J.B., 1972. 
mão e toca tudo o que ele possui... e ele Te almadiçoará na Tua face!" Zuss resolve então testar a crença de J.B., retirando-lhe tudo, dando-lhe o sofrimento. Coloca a máscara de Deus e é questionado por Nickles que não entende por que J.B. deve sofrer. Sr. Zuss responde que "a dor ensina!" Em cada uma das cenas subseqüentes, uma desgraça se abate sobre o lar de J.B.: na terceira cena, dois mensageiros vestidos de soldados trazem a notícia da morte de David, filho mais velho do casal; na quarta, um acidente de carro tira violentamente a vida de dois de seus filhos, Maria e Jonas; na quinta, o casal J.B. e Sara procuram por Rebeca que sumiu, se dirigem até a polícia e ficam sabendo que a menina de vestido branco com sapatos e sombrinha vermelhos fora estuprada e assassinada por um garotão. Nickles, no final da quinta cena, já está furioso com sr. Zuss e, sempre usando metalinguagem, os dois falam da representação a que estão assistindo. Para Nickles, J.B. já "sabe o nome do sofrimento", mas sr. Zuss o conduz a seus devidos lugares para assistirem ao restante do sofrimento de J.B. na cena seguinte. Na sexta cena, J.B., com roupas rasgadas, está entre ruínas, pois o quarteirão todo sumiu, o Banco e a firma de J.B. viraram cinzas. Sara se desespera diante daquele buraco que levou os milhões de J.B. e matou a última filha esmagada, Rute. Mesmo vivenciando tantas desgraças, J.B. se mantém crente em Deus:

Sara!

Mesmo desesperados não podemos desesperar

Não nos larguemos a mão - não

Submerjamos no fundo

Torpor de um silêncio insípido

Afogados em nosso íntimo gelado

Não podemos!

Deus também está no desespero.

Não sei porque é que Ele atinge,

Mas também Ele é atingido;

Vida é desespero, misturada à morte,

Mas um desespero que ainda é vida...

Sara!

Não largue minha mão, Sara!

Repita comigo:

O Senhor

Dá... diga. 
J.B. é interrompido e Sara, afastando a mão, grita: "Tira! Mata! Mata! Mata! Mata!" Na sétima cena, sr. Zuss e Nickles comentam os acontecimentos e Nickles se convence de que sr. Zuss, Deus, tinha razão. Na oitava cena, J.B. já está em trapos, os vizinhos e alguns transeuntes, sra. Murphy, sra. Adams, sra. Lesure, se espantam com o estado em que se encontra o antigo milionário. Sara inconformada o abandona e J.B. fica sozinho. O antigo milionário pede a morte na nona cena e roga por Deus, mas quem vem até ele são três consoladores, Zophar, Bilbad e Eliphaz. J.B., no final dessa cena, volta-se para Deus e diz:

Ouve, eu te suplico, e falarei...

meus ouvidos tinham escutado falar de Ti

Mas agora

... meus olhos te vêem

Por isso

É que me execro... e me arrependo...

Na penúltima cena, Nickles reconhece que sr. Zuss estava certo e, continuando o discurso metalingüístico, ambos se elogiam pela representação, mas ainda não é o fim. Sr. Zuss pede "Luzes! Luzes!" e, apesar de já terem cumprimentado o público, "há sempre uma cena a mais", segundo sr. Zuss. Na última cena, décima primeira, Sara retorna e traz uma forsítia, com as primeiras folhinhas, nem ao menos folhas, pétalas... que descobriu entre as cinzas em que se transformou a cidade e, com essa metáfora, J.B. e Sara caminham, no final, levantando cadeiras, e J.B. tem sua última fala:

Veremos onde estamos.

O espírito não se consumirá e a lama molhada se Acende mesmo sem chama.

Sobre as brasas do coração e então veremos...

Saberemos...

A paráfrase da peça nos dá a dimensão religiosa do texto a que Clarice assiste e sobre o qual escreve a crítica, na qual temos quase que exclusivamente as impressões sobre o texto de Archibald Mac Leish e não sobre a encenação teatral, premiada com o Tony Awards em 1959 de melhor autor, melhor diretor (Elia Kazan) e produtor (Alfred de Liagre). Sobre o espetáculo, Clarice cita os atores responsáveis pelos principais papéis, Raymond Massey, representando Deus, Christopher Plummer no papel de Satanás e Pat Hingle 
como o protagonista da peça J.B. A comentarista destaca, no início do texto, as "reações variadas" dos espectadores, pois "houve os que se reemocionaram com Job, houve os que se comoveram com 'J.B.', o homem de negócios e os que choraram os próprios males, pois teatro é lugar quente neste frio daqui”. A metáfora contida na citação revela o quanto Clarice está sempre impregnada da linguagem literária, própria de seus contos e romances. ${ }^{46}$ O discurso metafórico deve-se, certamente, à temática do espetáculo a que assiste, pleno de religiosidade e de reminiscências de um dramaturgo-poeta que participou como soldado durante a guerra ${ }^{47}$ e coloca agora em cena o estado de ruína das cidades e de destruição de homens como J.B. Assim, a afirmação metafórica nos permite presumir que a autora, mais do que tratar de questões climáticas, sugere quão distanciadas e frívolas tornaram-se as relações entre os Homens, principalmente, entre aqueles que têm, como J.B., poder aquisitivo para freqüentar teatros e estão ao mesmo tempo marcados pelas lembranças de uma segunda guerra encerrada havia pouco mais de década.

É sobre o texto que as impressões de Clarice se concentram, principalmente, sobre as relações inegáveis entre o texto do Antigo Testamento e a peça de Mac Leish, relações que resultaram em considerações positivas e outras negativas, pois "alguns consideraram a peça um acontecimento literário, que uma vez no palco, se transformou numa simples reafirmação do Antigo Testamento - com menos dramaticidade que este, e as melhores frases tiradas do próprio Livro de Jó". E Clarice se posiciona, afirmando que "J.B., porém não

46. Aparecida Maria Nunes, em sua dissertação de mestrado, Clarice Lispector jornalista, afirma: "Concluo, então, que Clarice Lispector exerceu um jornalismo peculiar, próximo de suas inquietações: de saber sobre a vida e sobre o ser humano. Ao aceitar trabalhar com o status quo, demonstrou estar atenta com as pequenas necessidades do dia-a-dia. No entanto, ela era uma personagem lisérgica. Para ela, se abriam as portas da percepção. Tinha uma visão absolutamente desbanalizante da realidade. Percebia uma inesgotabilidade de impressões. Ela era uma pessoa prodigiosamente intuitiva, de tal forma que era inundada por uma urgência de exprimir aquilo que nela era a crepitação de sua vida psíquica e da soma enumerada de experiências que acumulava. Como disse Hélio Pellegrino, com o qual concordo inteiramente". NUNES, 1991, p. 253-254.

47. Clarice vive no exterior por quase 16 anos. O primeiro lugar no exterior em que ela reside é Nápoles, em plena Grande Guerra Mundial, por isso trabalha como ajudante em um hospital de soldados brasileiros. 
é a dramatização de um incidente da Bíblia, nem a modernização da tragédia de Job”. O texto crítico mistura afirmações da própria autora com as de Mac Leish, que relata sobre a construção da "peça moderna dentro da antiga majestade bỉblica" e das diferenças entre os dois textos. Em parágrafos referenciais, Clarice sintetiza o enredo da peça, caracterizando a personagem-título, "chamado ao jeito moderno pelas iniciais" J.B. e cita trechos escritos sobre a peça por Mac Leish ao se referir aos questionamentos de J.B. que se assemelham aos de Job, pois "Job não é respondido pela voz que vem do verbo rodopiante. É silenciado pela voz silenciado por uma das trinta ou quarenta linhas de maior grandeza em toda a literatura - silenciado pelo poder e majestade e magnificência da criação. É levado não a entender, mas a ver. Como nós". O parágrafo final informa de outro espetáculo também sobre os "lamentos de Job". Apresentado pela Escola de Música Julliard, o oratório dramático Job, de Luigi Dallapicolla.

Sabemos que a escritura de Lispector se destaca pela linguagem metafórica e está impregnada de religiosidade, ${ }^{48}$ basta atentarmos para alguns títulos de seus romances, A paixão segundo G.H., A via crucis do corpo, A maçã no escuro e a tragédia A pecadora queimada e os anjos harmoniosos. Olga de Sá enumera algumas afirmações a respeito da ficção clariciana, das quais destacamos a seguinte:

Clarice Lispector tem atrás de si uma linguagem secular, a dos que se situam do lado não iluminado das coisas. É a verdade sombria da literatura ocidental, que Auerbach filia à tradição bíblica do Velho testamento, em contraste com a explicação do realismo homérico. É por essa vocação bíblica que se pode falar no sentido da parábola da obra, que às vezes irrompe à superfície. ${ }^{49}$

Essa vocação bíblica está, por exemplo, na tragédia escrita pela autora, A pecadora queimada e os anjos harmoniosos, mais ou menos uma década antes do espetáculo assistido por Clarice. Essa tragédia tem, como o título evidencia, a ação dramática construída a partir da traição de uma mulher, considerada pecadora, em uma leitura contemporânea do sétimo mandamento da Lei de Deus, "não cometerás adultério". Essa vocação bíblica estará presente no romance publicado em 1964, A paixão segundo G.H.

48. Ricardo Iannace, em A leitora Clarice Lispector, aponta as várias referências a textos bíblicos e citações bíblicas nos textos da autora.

49. SÁ, 1979, p. 64. A afirmação é feita sobre o romance A paixão segundo G.H. 
Apesar da distância temporal, A paixão segundo G.H. é o romance escrito após a crítica da peça J.B. Apoiando-nos nas teorias bakhtinianas, podemos identificar e analisar alguns pontos de contato entre o texto dramático e o romance clariciano que demonstram que "todo texto se constrói como mosaico de citações, todo texto é absorção e transformação de um outro texto", 50 com a intenção de focar algumas possíveis relações que podem ser estabelecidas entre o texto dramático assistido e o romance escrito por Clarice. Coincidência ou não, tal como J.B., a protagonista do romance é chamada "ao jeito moderno, pelas iniciais" e tem, materialmente falando, tudo o que um homem deseja ter. O romance, o primeiro narrado em primeira pessoa, não relata apenas o comportamento de uma mulher burguesa, G.H., que reside em um apartamento e se depara, no quarto vazio da empregada que a deixou, com uma barata, mas vai além, revelando os autoquestionamentos de alguém que está sofrendo uma transformação de seus conceitos à luz de uma experiência transcendental.

O texto dramático foi construído dentro "da majestade bíblica", o título do romance nos remete, na história dos cristãos, ao sofrimento de Jesus Cristo. O termo "paixão", em grego pathein, significa "ter padecido", pois se refere ao sofrimento e à morte de Cristo, mas aparece também na bíblia como desejo ou concupiscência. ${ }^{51}$ A trajetória de J.B. da luxúria à pobreza pode ser comparada à de G.H., que se desloca dentro de seu apartamento luxuoso para dirigir-se à simplicidade do quarto da empregada Janair e ali se deparar com a barata. Em um deslocamento de perdas, resta para G.H. um quarto que recebe mais a luz solar e uma barata. No quarto humilde da empregada, G.H. sente-se aliviada, "de repente aquele mundo inteiro que eu era crispava-se de cansaço, eu não suportava mais carregar os ombros" e, ao se deparar com a barata, G.H., mergulhada em um mundo de indagações subjetivas, expressa o medo de ver a verdade,

mas o meu medo não era o de quem estivesse indo para a loucura, e sim para uma verdade - um medo era o de ter uma verdade que viesse a não querer, uma verdade infamante que fizesse rastejar a ser do nível da barata. Meus primeiros contatos com a verdade sempre me difamaram. ${ }^{52}$

50. KRISTEVA, apud REUTER, 1995, p. 146.

51. Termo comumente utilizado em A pecadora queimada e os anjos harmoniosos.

52. LISPECTOR, 1997, p. 64. 
Tal como J.B., G.H. é conduzida e se deixa conduzir, pois está sendo levada para se ver e nas dificuldades se enxergar. Se, na miséria, em farrapos, na perda de tudo e de todos, J.B. vê e recomeça, assim G.H. se vê na queda $^{53}$ e afirma: "era como se eu tivesse morrido e desse sozinha os primeiros passos em outra vida". Como diz Soren Kierkegaard, "o que importa é encontrar uma verdade que seja verdade para mim, encontrar a idéia pela qual possa viver e morrer", ou ainda como diz Cristo, "em verdade, em verdade vos digo que se alguém não nascer de novo, não pode ver o reino de Deus". ${ }^{54}$ Tal como J.B. que tem, segundo a crítica, "as melhores frases tiradas do próprio Livro de Jó", palavras bíblicas são freqüentes neste romance clariciano, como "glória divina", "perdão", "cântico de ação de graças", "redenção", "deserto" e "bíblia". Além disso, termos como luz, odiar e revelar, próximos do evangelho de São João, são também freqüentes no romance e G.H. os reúne ao dizer "como odeio a luz do sol que revela tudo". As referências à Bíblia são variadas e, depois de comer a barata, ela cospe e diz: "eu cuspia a mim mesma". N5 Nese momento, parece que ela aceita o que era, mas rejeita e sente nojo. É nesse instante que ela cita Apocalipse (capítulo 3, versículo 16), "porque não é frio e nem quente" ${ }^{56}$ e se diz aproximar do divino, "eu que pensara que a maior prova de transmutação de mim em mim mesma seria botar na boca a massa branca da barata. E que assim me aproximaria do... divino? do que é real?".

Este é o auge da experiência de G.H., que a faz rever sua vida, tal como J.B., que "precisa soprar as brasas do coração e ver aos pouquinhos e saberemos". As reticências finais, fechando o texto dramático, e a rubrica pedindo uma "luz que intensifica, até filtrar-se pela porta a simples claridade crua do dia, à medida que os dois trabalham", deixam em aberto o que J.B. e Sara vão ver e saber, como os seis travessões que se unem aos seis travessões do início

53. Assis Brasil aproxima o existencialismo de Clarice Lispector ao de Kierkegaard e não ao de Albert Camus e a queda tem, segundo o ensaísta, o mesmo sentido kierkegaardiano, "a queda é o mesmo de Kierkegaard: cair para se levantar purificado". (BRASIL, 1969, p. 85).

54. Bíblia Sagrada. Evangelho de João, capítulo 3, versículo 3.

55. LISPECTOR, 1997, p. 170.

56. LISPECTOR, 1997, p. 170.

57. LISPECTOR, 1997, p. 171. 
do texto no romance, indicando o silêncio de G.H. diante da constatação de que "a vida se me é" e na busca de compreender o que ela própria diz:

(...) o mundo independia de mim, e não estou entendendo o que estou dizendo, nunca! Nunca mais compreenderei o que eu disser. Pois como poderia eu dizer sem que a palavra mentisse por mim? Como poderei dizer senão timidamente assim: a vida se me é. A vida se me é, e eu não entendo o que digo. E então adoro.

O comentário teatral publicado por Paulo Francis em dezembro de 1958 antecipava o início de uma nova etapa na vida de Clarice Lispector. O período ${ }^{58}$ entre a escritura dos romances $A$ maçã no escuro, iniciada em 1951 e finalizada em 1956, e A paixão segundo G.H., em 1964, é dedicado à elaboração dos contos que serão posteriormente publicados em Alguns contos, ${ }^{59}$ em 1952, e em Laços de família, em 1960. Em 1959, enquanto o casal J.B. reata e vai em busca do que ver e saber, Clarice retorna ao Brasil separada e com seus dois filhos, Pedro e Paulo. Devido a dificuldades financeiras, pois é impossível viver dos direitos autorais de seus livros, e apesar da pensão que recebe do exmarido, Maury Gurgel Valente, ela amplia sua atividade como jornalista: continua escrevendo para a revista Senhor, mantém, em 1959, uma coluna no Correio da Manhã; em 1960, escreve no Diário da Noite e, de 1967 a 1973, intensifica o trabalho como cronista no Jornal do Brasil.

58. Lícia Manzo diz o seguinte sobre esse período: "O desafio de colaborar para três lugares simultaneamente (revista Senhor, jornais Correio da Manhâ e Diário da Noite), somado à administração integral da casa, e ainda a dor da separação misturada à dificuldade de adaptação de seus filhos ao novo sistema de vida, tudo isso parecia consumir Clarice, fazendo com que se afastasse novamente de sua produção literária. Ao todo seriam mais seis anos sem escrever". MANZO, 1997, p. 68.

59. São seis os contos publicados em Alguns contos: "Amor", "Começos de uma fortuna", "Uma galinha", "A fuga", "Os laços de família" e "O jantar". Esses contos serão publicados junto com outros em Laços de família. Rio de Janeiro: Francisco Alves, 1960. 
Disponível em: bttp://www.letras.ufmg.br/poslit

Abstract: The following article aims for analyse Clarice Lispector's correspondence, in order to emphasize the involvement as a writer with theatre through ber appreciations on dramatic arts, and her interest for the theatre outlook at that time. We are also attaching a journalistic article - still unpublished - in which Clarice Lispector make her comments about the putting on stage of the playbill J.B., written by the poet Archibald MacLeish, sucess of critic and audience on Broadway in 1958.

Key words: Brazilian Literature; Epistolography; Theater; Clarice Lispector.

\section{Referências Bibliográficas}

ABREU, Caio Fernando. A hora de Clarice no Cinema. O Estado de S. Paulo, São Paulo, mar. 1986.

ARÊAS, Vilma. A moralidade da forma. Minas Gerais, Belo Horizonte, 19 dez. 1987. Suplemento Literário, n. 109, p. 12-14. Número especial: Lembrando Clarice (Org.: Nádia Batella Gotlib).

ARÊAS, Vilma. O sexo dos clowns. Tempo Brasileiro, n. 104, Rio de Janeiro, p. 145-154, jan.-mar., 1991.

ARÊAS, Vilma. Que mistérios tem Clarice? Folha de S. Paulo, São Paulo, 29 nov. 1977.

BORELLI, Olga. Clarice Lispector: Esboço para um possível retrato. Rio de Janeiro: Nova Fronteira, 1981.

BRASIL, Assis. Clarice Lispector: Ensaio. Rio de Janeiro: Organização Simões, 1969.

CASTRO, Ruy. O anjo pornográfico: A vida de Nelson Rodrigues. São Paulo: Companhia das Letras, 1992.

CORDOVANI, Glória M. Clarice Lispector: Esboço de uma bibliografia. 1991. Dissertação (Mestrado) - FFLCH-USP, São Paulo.

FERREIRA, Teresa Cristina Montero. Eu sou uma pergunta: uma biografia de Clarice Lispector. Rio de Janeiro: Rocco, 1999.

FITZ, Earl E. A Pecadora queimada e os Anjos harmoniosos: Clarice Lispector as Dramatist. Luso Brasilian Review, v. 3, 1997.

GOTLIB, Nádia Battella. Biografia mostra Clarice além da ficção. O Estado de S. Paulo, São Paulo, 11 jun. 1994.

GOTLIB, Nádia Battella. Clarice, um retrato digno. Folha de S. Paulo, São Paulo, 21 ago. 1983.

GOTLIB, Nádia Battella. Clarice: uma vida que se conta. São Paulo: Ática, 1995.

GUIMARÃeS, Adriana. Passeio literário pelas escrituras de mim. As cartas de Lúcio Cardoso e Clarice Lispector. 1998. Dissertação (Mestrado) - PUC, Rio de Janeiro.

IANNACE, Ricardo. A leitora Clarice Lispector. São Paulo: Edusp; Fapesp, 2001.

KRISTEVA, Julia. Sèméiôtiké. Apud REUTER, Yves. Introdução à análise do romance. São Paulo: Martins Fontes, 1995.

LISPECTOR, Clarice. A legião estrangeira (1964). Rio de Janeiro: Ed. do Autor, 1964; A legião estrangeira. São Paulo: Ática, 1977. 
LISPECTOR, Clarice. A paixão segundo G.H. (1964). Edição crítica. (Coord.: Benedito Nunes). Paris: ALLCA XX; Brasília: CNPq, 1988; A paixão segundo G.H. Rio de Janeiro: Editora Sabiá Limitada, s.d.; A paixão segundo G.H. Ed. Crítica [Coord.: Benedito Nunes]. São Paulo: Scipione Cultural, 1997.

LISPECTOR, Clarice. Cartas perto do coração/Fernando Sabino e Clarice Lispector. Rio de Janeiro: Record, 2001.

LISPECTOR, Clarice. Correspondências/Clarice Lispector(Org.: Teresa Montero). Rio de Janeiro: Rocco, 2002.

LISPECTOR, Clarice. Depoimento a Affonso Romano de Sant'Anna, Marina Colasanti e João Salgueiro, em Coleção depoimentos, n. 7, Museu da Imagem e do Som. Rio de Janeiro, 20 de outubro de 1976.

LISPECTOR. Clarice Lispector escreve sobre J.B. [Coluna de Paulo Francis]. Diário Carioca, 21 dez. 1958.

LISPECTOR, Clarice. Perto do coração selvagem (1943). 15. ed. Rio de Janeiro: Francisco Alves, 1992.

MAC LEISH, Archibald. J.B. Trad. Lélia C. Frota. Rio de Janeiro: Agir, 1972

MAGALDI, Sábato. Nelson Rodrigues: Dramaturgia e encenações. São Paulo: Perspectiva, 1987.

MAGALDI, Sábato. O texto no teatro. São Paulo: Perspectiva; Ed. da Universidade de São Paulo, 1989.

MANZO, Lícia. Era uma vez: eu - a não-ficção na obra de Clarice Lispector. Curitiba: Secretaria de Estado da Cultura; The Document Company-Xerox do Brasil, 1997.

MARTINS, Gilberto. Alter(c)idades - um exercício de escalas. 2002. Tese (Doutorado) FFLCH-USP, São Paulo.

NUNES, Aparecida Maria. Clarice Lispector jornalista. 1991. Dissertação (Mestrado) FFLCH-USP, São Paulo.

NUNES, Benedito. O dorso do tigre. São Paulo: Perspectiva, 1969.

NUNES, Benedito. O drama da linguagem. São Paulo: Ática, 1989.

PRADO, Décio de Almeida. O teatro brasileiro moderno. São Paulo: Perspectiva; Edusp, 1998.

ROUBINE, Jean-Jacques. A linguagem da encenação teatral. 2. ed. Trad. Yan Michalski. Rio de Janeiro: Jorge Zahar, 1998.

SÁ, Olga de. A escritura de Clarice Lispector. Petrópolis: Vozes; Lorena: Faculdades Integradas Teresa D'Ávila, 1979.

STANISLAVSKI, Constantin. A preparação do ator. 7. ed. Rio de Janeiro: Civilização Brasileira S.A., 1986a.

STANISLAVSKI, Constantin. A construção da personagem. 4. ed. Trad. Pontes de Paula Lima. Rio de Janeiro: Civilização Brasileira, 1986b.

VASCONCELLOS, Eliane (Org.). Inventário Clarice Lispector. Rio de Janeiro: Fundação Casa de Rui Barbosa, 1993.

WALDMAN, Berta. A paixão segundo Clarice Lispector. $2^{\underline{a}}$ ed. rev. e aum. Campinas: Escuta, 1992; São Paulo: Brasiliense, 1981.

WALDMAN, Berta. O estrangeiro em Clarice Lispector: Uma leitura de $A$ bora da estrela. In: ZILBERMAN, Regina et al. Clarice Lispector: a narração do indizível. Porto Alegre: Artes e Ofícios, 1998. 